An analysis of public policy issues and how they

affect MRS members and the materials community..

\title{
FMS Letter to Congress Supports Federal Funding of University Research
}

The following text is a letter signed by the presidents of the Federation of Materials Societies (FMS) and 10 of its member societies, sent to members of the U.S. House and Senate Budget, Appropriations, Science, Energy, and Armed Services Committees in support of university research. The letter supports an advertisement (see sidebar) placed in the Washington Post, May 2, 1995, signed by the heads of 16 corporations, stressing the importance of federally funded research. Julia $M$. Phillips signed the letter as president of the Materials Research Society.

On May 2, 1995, an advertisement appeared in the Washington Post that clearly stated the connection between the quality of life that Americans enjoy today and the science and technology research that have taken place in our universities, largely under government support, for many decades. Signed by the heads of 16 corporations, the letter emphasizes the relationship between the research and training capabilities of American universities, the financial support of the federal government, and the transformation of fundamental knowledge into real-world products by industry that has been criti-

\section{A Moment of Truth for America}

Imagine life without polio vaccines and heart pacemakers. Or digital computers. Or municipal water purification systems. Or space-based weather forecasting. Or advanced cancer therapies. Or jet airliners. Or disease-resistant grains and vegetables. Or cardiopulmonary resuscitation (CPR).

We take for granted these and thousands of other technological breakthroughs that have made American society the most advanced in history. They have made our economy more competitive, created millions of jobs, and underpinned our entire standard of living. They have vastly improved our health and extended our life span. In a very real sense, they epitomize the American Dream.

But these breakthroughs didn't just happen. They are the products of a long-standing partnership that has, as a matter of national policy, fostered the discovery and development of new technologies. For many years, Administrations of both parties, working with Congress, have consistently supported university research programs as a vital investment in our country's future. Industry has played an equally critical role, carefully shepherding these new technologies into the marketplace.

This partnership - the research and educational assets of American universities, the financial support of the federal government and the real-world product development of industry-has been a critical factor in maintaining the nation's technological leadership through much of the 20th century.

Just as important, university research has also helped prepare and train the engineers, scientists and technicians in industry whose discipline and skill have made technological breakthroughs possible. It has sparked innovation and prudent risk-taking. And as a result of the opportunity afforded such skilled workers in our technologically advanced economy, many disadvantaged young people have used high-tech jobs as a "stepping stone" to more productive and satisfying lives.

Unfortunately, today America's technological prowess is severely threatened. As the federal government undergoes downsizing, there is pressure for critical university research to be slashed.

University research makes a tempting target because many people aren't aware of the critical role it plays. It can take years of intense research before technologies emerge that can "make it" in the marketplace. History has shown that it is federally sponsored research that provides the truly "patient" capital needed to carry out basic research and create an environment for the inspired risk-taking that is essential to technological discovery. Often these advances have no immediate practical usability but open "technology windows" that can be pursued until viable applications emerge. Such was the case with pioneering university research done on earthquakes in the 1920s, which led over time to the modern science of seismology and the design of structures that better withstand earthquake forces.

Today, we, the undersigned - executives of some of America's leading technology companies-believe that our country's future economic and social well-being stands astride a similarly ominous "fault line." We can personally attest that large and small companies in America, established and entrepreneurial, all depend on two products of our research universities: new technologies and well educated scientists and engineers.

Technological leadership, by its very nature, is ephemeral. At one point in their histories, all the great civilizations-Egypt, China, Greece, Rome-held the temporal "state of the art" in their hands. Each allowed their advantage to wither away, and as the civilization slipped from technological leadership, it also surrendered international political leadership.

For all these reasons it is essential that the federal government continue its traditional role as funder of both basic and applied research in the university environment. If we want to keep the American Dream intact, we need to preserve the partnership that has long sustained it. As we reach the final years of the century, we must acknowledge that we face a moment of truth:

Will we nurture that very special innovative environment that has made this "the American century?" Or will we follow the other great civilizations and yield our leadership to bolder, more confident nations? As the Congress makes its decisions on university research, let there be no mistake: We are determining the 21st century today.

\section{W. Wayne Allen, Chairman \& CEO, Phillips Petroleum Company}

George M.C. Fisher, Chairman, President \& CEO, Eastman Kodak Company

Gerald Greenwald, Chairman \& CEO, United Airlines

Randall L. Tobias, Chairman \& CEO, Eli Lilly and Company

Norman R. Augustine, President, Lockheed Martin Corporation

Robert W. Galvin, Chairman, Executive Committee,

Motorola, Incorporated

George H. Heilmeier, President \& CEO, Bellcore

P. Roy Vagelos, M.D., Former Chairman \& CEO,

Merck \& Company, Incorporated

John L. Clendenin, Chairman \& CEO, BellSouth Corporation

Louis V. Gerstner, Jr., Chairman \& CEO, IBM Corporation

Jerry R. Junkins, Chairman, President \& CEO,

Texas Instruments, Incorporated

John F. Welch, Chairman \& CEO, General Electric Company

Robert J. Eaton, Chairman \& CEO, Chrysler Corporation

Joseph T. Gorman, Chairman \& CEO, TRW, Incorporated

John McDonnell, Chairman, McDonnell Douglas Corporation

Edgar S. Woolard, Jr., Chairman \& CEO,

E.I. DuPont DeNemours and Company 
cal in "maintaining the nation's technological leadership through much of the 20th century."

As the representatives of professional societies representing practicing materials scientists and engineers in all 50 states and in all sectors of the economy from academia to government organizations to industry, we strongly support the message of the May 2 letter. Our standard of living is directly related to government funded fundamental advances made in the universities which have been transformed by our industries into products that have dramatically changed our world. In the process, students have been trained for positions in all sectors, leading to more jobs, increased productivity, and further technological breakthroughs. Seriously injuring fundamental science and engineering research in the universities or its links to industry will have dire consequences for America as we enter the 21 st century.

The examples of the success of the academia-government-industry partnership are everywhere and include advances in health care such as magnetic resonance imaging and time-release medications, progress in communications such as fiber optics and lasers which have created the information superhighway, composite materials and unusual alloys which enable new generations of aircraft and auto and industrial catalysts vital in pollution reduction. Science and engineering research paces our progress and delineates national competitiveness in transportation, aerospace, electronics, environmental remediation, infrastructure renewal, bio-prostheses, communications, commuting, energy production and utilization and national defense.

The Federation of Materials Societies (FMS) is an umbrella organization whose member societies and affiliates represent the professional societies and universities which are involved with materials science, engineering and technology. FMS constituent societies have more than 700,000 members.

Materials is an interdisciplinary field stretching over a wide variety of disciplines including ceramics; corrosión; electrical, mechanical, environmental, chemical and civil engineering; glass; metallurgy; materials testing; polymers, composites, bio-materials, electronic materials; solid state chemistry; condensed matter physics; welding, joining, and cutting; and standards. University materials education and research involves materials science and engineering departments. In addition many activities in physics, chemistry, ceramics, metallurgy, polymer, electrical, mechanical and chemical engineering departments have a large materials content. Materials are important to most manufacturing industries and almost all consumer products.
In short, university research is a primary driver and enabler for most progress in materials science and engineering which is central to economic competitiveness and quality of life now and in the future.

Sincerely,

Robert A. Laudise

President, FMS

Brian M. Rushton.

President, American Chemical Society

David G. Howden

President, American Welding Society

Richard D. Gonzalez

President, North American Catalysis Society

Joseph F. Wenckus

President, American Association

for Crystal Growth

C.K.N. Patel

President, American Physical Society

James A. Amick

President, The Electrochemical Society, Inc.

Paul G. Campbell

President, The Minerals, Metals \&

Materials Society

David Johnson

Immediate Past President, The American

Ceramic Society, Inc.

William C. Plumstead

President, American Society for

Nondestructive Testing

Julia M. Phillips

President, Materials Research Society

\section{Are you planning a conference or short course? Promoting books or journals? Announcing your latest software?}

A mailing list from the Materials Research Society is exactly what you need! Over 120,000 names of scientists and research managers who are active in forefront areas of materials research and engineering. Lists are grouped in four main categories:

- Materials by application

- Materials characterization
- Materials by properties

- Materials processing

\section{MRS Mailing List Rental ...}

... reaching the broadest range of materials professionals directly!

Call today for more information or fax your order to: Mary E. Kaufold

Materials Research Society, 9800 McKnight Road, Pittsburgh, PA 15237-6006

Telephone (412) 367-3036; Fax (412) 367-4373; E-mail: Kaufold@mrs.org 